Research Article/Araştırma Makalesi

\title{
The Study of Developing a "Motivation Scale Intended for Turkish Course" Towards Secondary School Students
}

\author{
Aysel ARSLAN *1 (D) Adnan TASGIN 2 \\ ${ }^{1}$ Cumhuriyet Üniversitesi, Sağlık Meslek Yüksekokulu, Çocuk Gelişimi Bölümü, Sivas, Türkiye, arslanaysel.58@gmail.com \\ 2 Atatürk Üniversitesi, Kâzım Karabekir Eğitim Fakültesi, Ĕ̆itim Bilimleri Bölümü, Erzurum, Türkiye, adnantasgin@gmail.com \\ * Corresponding Author: arslanaysel.58@gmail.com
}

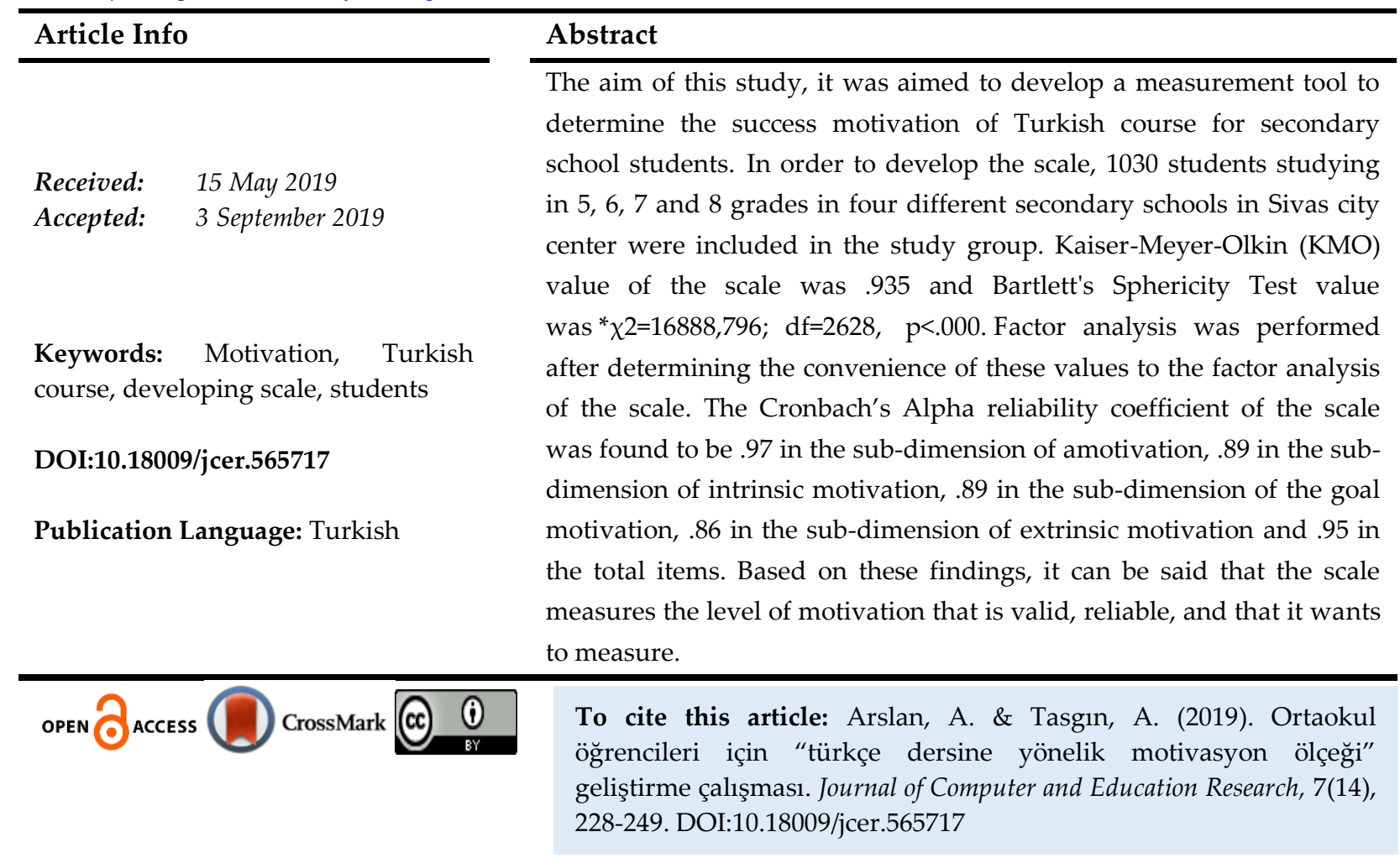

\section{Ortaokul Öğrencileri İçin “Türkçe Dersine Yönelik Motivasyon Ölçeği" Geliştirme Çalışması}

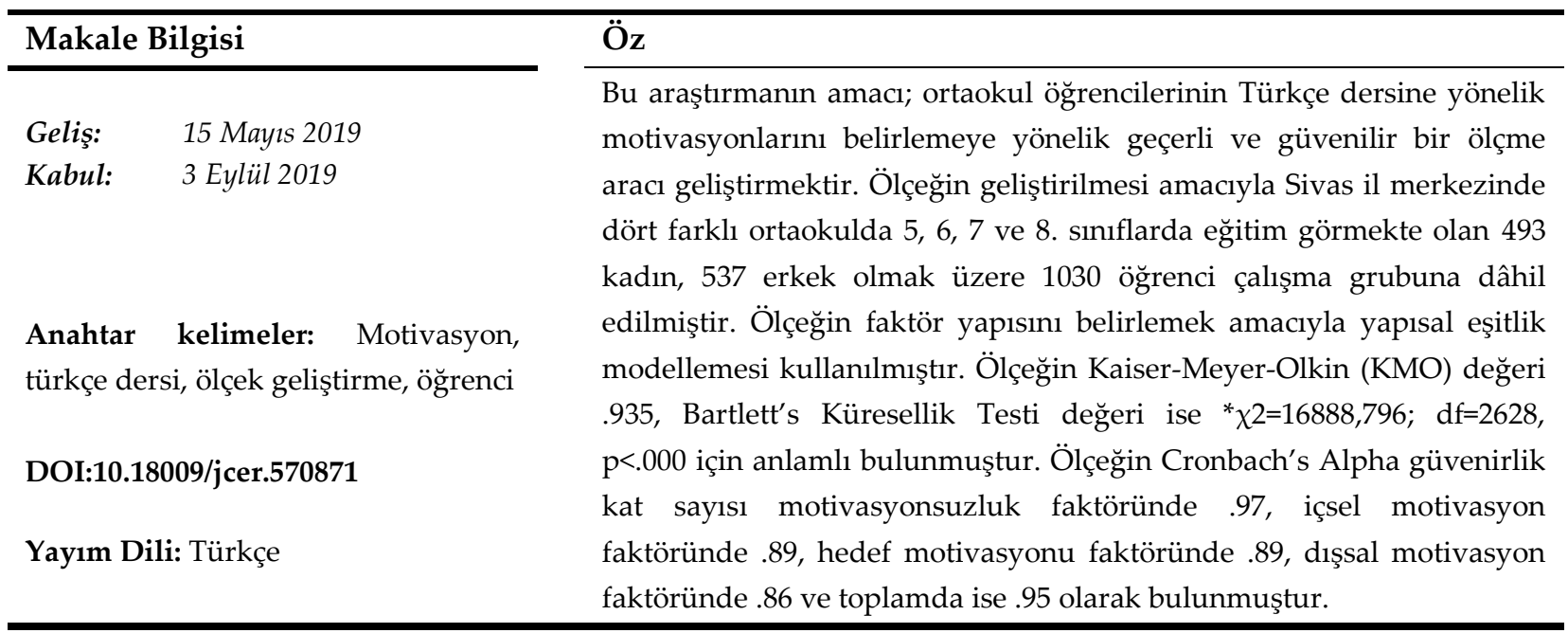




\section{Summary}

\section{The Study of Developing a "Motivation Scale Intended for Turkish Course" towards Secondary School Students}

\section{Introduction}

Motivation is a very widespread concept that includes motive, desire, necessity, impulse and interest, and defined as the individual's struggle in the form of self-effort, taking action and exhibiting certain behaviors to achieve the goal desired. Motivation is effective to achieve the desired goal not only in the beginning of the movement, but also in directing and sustaining it. It is stated that motivation is a force that motivates, maintains and positively directs the individual to realize our purpose. In order to have a high-level motivation for a job, the individual should determine formerly our purpose, the reasons for our attitude and behaviors in order to achieve our purpose and the reasons to maintain our motivation. To be meaningful for the individual and at the quality of giving our the fighting power you needs, the reasons determined become important in dealing with the negativities that are encountered in the process of achieving success. It is stated that the impulse, interests, desires and needs of the individual are important in creating these reasons.

Different theories have been formed regarding the concept of motivation. Principal of these are "Expectation-Value Theories", "Goal Theories" and "Self-Determination Theories". It is stated that expectation-value theories are related to the success of the individual in our job and the value you brings to the result of the success obtained. Goal theories basically argue that the goal that the individual wants to reach has a decisive impact on our motivation. Selfdetermination theories are based on the concepts of intrinsic and extrinsic motivation, which is one of the most distinctive aspects of the concept of motivation. Thus, according to this theory, motivation is generally considered in two different categories as intrinsic motivation and extrinsic motivation. The focus of control that determines the behavior of the individual determines the motivation to be defined as internally or externally. If an individual carries out his/her behavior through motivation based on his/her beliefs and expectations, you focus on internal control and if you consider the external stimuli, you focus on external control. Intrinsic and extrinsic motivation affects each other. The motivation source that determines 
the behavior of the individual can differentiate in the process. The individual is motivated for any reward, whether motivated or not, and after performing our behavior, you is able to perform it because likes it. On the contrary, the individual is able to motivate her after she fulfills her behavior primarily because she loves it, or after it, after her material or spiritual rewards. The creativity, research, learning, academic success, sustainability of the work, etc. it is stated to be effective and important in many issues. Motivation has a significant impact on the success of students in learning environments. Failure to take students' motivation for learning into consideration is negatively affecting the realization of instruction at the desired level. In this study, it was aimed to develop a measurement tool to determine the success motivation of Turkish course for secondary school students.

\section{Method}

In order to develop the scale, students who were studying in 5, 6, 7 and 8 grades in four different secondary schools in the city center of Sivas were included in the study group. 93 students were used for the pre-application of the scale, 938 students for Exploratory Factor Analysis (EFA) and 568 for Confirmatory Factor Analysis (CFA). Structural equation modeling was used to develop the scale. By applying exploratory factor analysis to the scale items, the scale was found to have a structure of six factor. Then, Monte Carlo analysis, which takes part in parallel analysis techniques, was performed in order to compare the determined factors with the critical eigenvalues by using principal component analysis.

\section{Result}

The results of the Monte Carlo parallelism test were compared with the scale factors and it was determined that the four dimensions of the scale were compatible. The other two dimensions determined as a result of the exploratory factor analysis were not accepted because they did not form the necessary conditions. Confirmatory factor analysis was applied to the accepted factors. According to the obtained model fit values, model $X^{2} / d f=$ 2.260, TLI $=.926$, RMSEA $=.047, S R M R=.046, C F I=.931, A G F I=.87, N F I=.90$ was found to fit perfectly to the data. According to the rotational factor loadings obtained by exploratory factor analysis, the scale consists of 4 factors including 45 questions. Factors are named by considering the means of the items in the factors. Scale was determined to be formed by four sub-dimensions named as "Amotivation", "Intrinsic Motivation", "Goal Motivation", and "Extrinsic Motivation". Factors are named by considering the means of the items. The scale explained $57 \%$ of the total variance. When the expression percentage of scale dimensions in 
total variance is examined, it was found that the first dimension expresses $32 \%$, the second dimension $15 \%$, the third dimension $4 \%$ and the fourth dimension $4 \%$, respectively. The total variance explained by the scale is expected to be $50 \%$ or more. In this respect, it was found that the variance explained by the scale is at the desired level. The Cronbach's Alpha reliability coefficient of the scale was found to be .97 in the sub-dimension of amotivation, .89 in the sub-dimension of intrinsic motivation, .89 in the sub-dimension of the goal motivation, .86 in the sub-dimension of extrinsic motivation and .95 in the total items. The reliability of the scale was found to be .92 for the first half and .95 for the second half in the half test analysis.

\section{Conclusion}

The findings show that the reliability of the scale is quite high. The validity of the motivation scale for the Turkish course with a total reliability of .95 was confirmed by the confirmatory factor analysis and it was decided that the scale could be used to measure the motivation levels of the secondary school students towards the Turkish course. The following proposal was presented to the researchers. With this scale, which is developed to determine the motivation of the secondary school students towards Turkish lesson, research can be done by using different variables. 


\section{Giriş}

Motivasyon; güdü, istek, gereksinim, dürtü ve ilgiyi içinde barındıran oldukça geniş bir kavram olup (Pintrich \& Schunk, 1996; Yapar, 2005: 4), bireyin karşılaştığ1 bir durum karşısında, istediği amaca ulaşmak için kendi isteğiyle çabalaması, harekete geçmesi ve belli davranışları göstermesi şeklinde tanımlanmaktadır (Lumsden, 1994). Viau (2015) bireyin varlığını devam ettirmesinde motivasyonun oldukça önemli bir etkisi olduğunu belirtmektedir. Motivasyon, istenilen amaca ulaşmak için sadece hareketin başlamasında değil sonrasında yönlendirilmesi ve sürdürülmesinde de etkili olmaktadır. Bireyin amacını gerçekleştirmesine yönelik olarak motivasyonun harekete geçirici, devamını sağlayıcı ve olumlu yöne yöneltici bir güç olduğu belirtilmektedir (Aslan \& Cengiz, 2015; Ilgar, 2000). Motivasyonun bireyin istek, arzu, ihtiyaç, amaç, amacının gerçekleştirilmesini olanaklı kılan davranışlar ve amacını gerçekleştirmeye dönük hareketlerinin sonuçlarına yönelik davranışlarıyla doğrudan bağlantısı bulunmaktadır (Koçel, 2014: 633). Motivasyon, genel anlamda bireyin istediği amaca ulaşmak için gerekli etkinlikleri ya da davranışları gerçekleştirmesine yönelik olarak istekli olması, arzu duyması şeklinde ifade edilmektedir (Aydın, 2007). Bireyin çabasını kontrol altına alarak başarıya ulaşmak için çabasını artırmasının mümkün olabileceği belirtilmektedir (Dörnyei \& Otto, 1998). Bu da motivasyonunun birey tarafından bilinçli olarak yükseltilmesinin mümkün olduğunu ortaya koymaktadır. Bireyin bir işe yönelik motivasyonunun üst düzeyde olması için; amacını, amacını gerçekleştirmek için ortaya koyduğu tutum ve davranışlarının nedenlerini, motivasyonunu sürdürebilmesi için gerekçelerini önceden belirlemesi gerekmektedir. Belirlenen gerekçelerin birey için anlamlı olması ve ihtiyaç duyduğu mücadele gücünü ona verecek nitelikte olması onun başarıya ulaşma sürecinde karşısına çıkan olumsuzluklarla başa çıkmasında önemli olmaktadır. Bireyin sahip olduğu dürtü, ilgi, arzu ve ihtiyaçlarının bu gerekçeleri oluşturmakta önemli olduğu belirtilmektedir (Koçel, 2014: 633). Ames (1990) bireyin amacına ulaşmasında motivasyonun oldukça önemli olduğunu kabul etmekle birlikte motivasyon ve başarının aynı şey olmadığını söylemektedir. Yüksek motivasyon, sonuca ulaşmak için süreçte bireye güç verirken bunun sonucunda birey başarılı olabilir ya da olmayabilir (Schunk, 2009). Çünkü başarı için motivasyonun dışında bilgi, zaman, çevre vb. pek çok koşulun da önemli olduğunu ifade etmektedir. 
Motivasyon kavramıyla ve yönelimiyle ilgili olarak farklı teoriler oluşturulmuştur. Bunların başlıcalarının "Beklenti-Değer Teorileri", "Hedef Teorileri" ve "Öz-Belirleme Teorileri" olduğu belirtilmektedir. Beklenti-değer teorileri; bireyin yaptığı işte başarılı olması ve elde ettiği başarının sonucuna yüklediği değerle ilgilidir. Yani bireyin başarıya yönelik ve başarının sonucunda elde edeceği değere yönelik beklentisi onun motivasyonu üzerinde olumlu ya da olumsuz bir etkiye sahip olmaktadır (Dörnyei, 1998). Beklenti değer teorileri de kendi içinde geçmiş yaşantılardaki deneyimleri kapsayan "Yükleme Teorisi" ve bireyin kendi bilgi ve becerilerine ilişkin algılarını kapsayan "Öz-Yeterlik Teorisi" altında iki kategoride incelenmektedir. Yükleme teorisi, bireyin bir konudaki başarı veya başarısızlıklarına ilişkin olarak geçmişteki deneyimlerinden yola çıkarak yapacaklarına ilişkin beklenti yüklemesi yapması (Weiner, 1979); öz-yeterlik teorisi ise bireyin bir işi yapma konusunda kendi yetkinliğine yönelik geliştirdikleri algının yapacağı işe ilişkin istek, çaba, sebat, yöntem seçiminde belirleyici olması şeklinde tanımlanmaktadır (Bandura, 1993). Hedef teorileri temelde bireyin ulaşmayı istediği hedefin onun motivasyonu üzerinde belirleyici bir etkisi olduğunu savunmaktadır. "Hedef Belirleme" ve "Hedef Yönelimi" olarak kendi içinde iki farklı kategoride yer almaktadır (Ataman, 2017). Hedef belirleme teorisinde bireyin bir hedefi belirlemesi ve ona ulaşmak için çaba göstermesi yer almaktadır. Hedef belirlerken hedefin net olarak belirlenmesinin ve hedefe ulaşılmasında yaşanan zorlukların, hedefleri gerçekleştirmeye ilişkin bağlılığın, birey için ulaştığı başarının önemini ve derecesini belirleyeceği ifade edilmektedir (Locke, 1996). Hedef yönelimi teorisi; bir konuda derin bilgi sahibi olmayı ve kendini geliştirmeyi içeren ustalık yönelimi ve ulaştığı bilgiyi uygulamaya dönüştürerek yeteneklerini sergilemeyi içeren icra yönelimi adı altında iki bileşenden oluşmaktadır. Ustalık yönelimli bireylerin bilgiye ulaşma ve derinleşmeyi, icra yönelimli bireylerin ise sahip oldukları yeteneklerini kullanarak diğer bireylere üstünlük sağlamayı amaçladıkları belirtilmektedir (Ames, 1992).

Öz-belirleme teorileri, motivasyon kavramı alanında en belirgin ayrımlardan biri olan içsel ve dışsal motivasyon kavramları üzerine kurulmuştur (Deci \& Ryan, 1985). Dolayısıyla bu teoriye göre motivasyon genel olarak içsel motivasyon ve dişsal motivasyon olarak iki ana kategoride ele alınmaktadır (Ryan \& Deci, 2000). Bireyin davranışlarını belirleyen denetim odağı motivasyonun içsel veya dışsal olarak tanımlanmasını ifade etmektedir. Birey davranışını kendi inançlarından ve beklentilerinden kaynaklı motivasyonla gerçekleştiriyorsa içsel denetime, dış uyaranları dikkate alarak gerçekleştiriyorsa dışsal 
denetime odaklanmaktadır (Başaran, 1996). İçsel motivasyon bireyin benlik duygusu ve inançlarıyla ilgili olup kendi hoşuna gittiği, merak ettiği, ilgisini çektiği ve memnun olduğu için davranışları gerçekleştirmesini ifade etmektedir (Odabaş, 2011). Birey öğrenmeye yönelik duyduğu ilginin sonucunda motive olmakta (Alexander \& Murphy, 1998), dışarıdan gelen uyarıcılara ve mükâfatlara ihtiyaç duymamakta, kendi bilişsel, duyuşsal, sosyal ve fiziksel gelişimlerini gerçekleştirmektedir (Ryan \& Deci, 2000). Bireyin bir konuda yetkinlik, özerklik kazanması, başkalarıyla etkileşim kurabilmesi için doğuştan gelen ihtiyaçlarını gidermeye yönelik olarak odaklanmış olması gerekmektedir (Ataman, 2017; Demirel, 2007). Dışsal motivasyonun daha çok çevreden gelen teşvikler, ödüller ve uyaranlarla ilgili olduğu belirtilmektedir (Deci \& Ryan, 2000). Bireyin davranışının ya da tutumunun sonucunda elde edeceği başarıya ilişkin olarak başkalarının memnuniyeti, alacağı övgü, ödül, para vb. etkenler motivasyon düzeyini belirlemektedir. İçsel ve dışsal motivasyon birbirini olumlu ya da olumsuz olarak etkilemektedir. Bireyin davranışını belirleyen içsel veya dışsal motivasyon kaynağı süreç içerisinde farklılaşabilmekte, başta içsel motivasyon iken sonrasında dışsal motivasyona ya da tam tersine dönüşebilmektedir. Birey elde edeceği maddi veya manevi, herhangi bir ödül için motive olup davranışını gerçekleştirirken elde ettiği sonuçlardan içsel keyif alarak sonrasında bunu sadece sevdiği için gerçekleştirebilmektedir. Tam tersi olarak da birey öncelikle sırf sevdiği için bir davranışı gerçekleştirirken sonrasında elde ettiği maddi veya manevi ödüller sonrasında onun motive olmasını sağlayabilmektedir (Schunk, 2009). Bireyin bir davranışı yapmaya yönelik isteksizlik duyması ise motivasyonsuzluk olarak ifade edilmektedir. Bireyin davranışının sonucunda elde edeceği maddi veya manevi ödüllere değer vermemesi, davranışı gerçekleştirme konusunda yetersiz görmesi, sonuca ulaşacağına inanmaması gibi nedenlere yönelik isteksizlik duyması motivasyonsuzluk olarak tanımlanmaktadır (Ryan \& Deci, 2000).

Bireyin motivasyon düzeyinin yaratıcılı̆̆ı, araştırması, öğrenmesi, akademik başarısı, başladığ1 işi sürdürebilmesi vb. pek çok konuda etkili ve önemli olduğu belirtilmektedir (Wolters, 1999). Bireyin tüm hayatında önemli bir etkiye sahip olan motivasyon özellikle öğrenme sürecinde akademik başarı üzerinde belirgin bir etkiye sahip bulunmaktadır (Ryan \& Deci, 2000). Öğrenme ortamlarında öğrencilerin başarılı olmasında motivasyonun oldukça önemli bir etkisi olduğu, öğrenme sürecinin sonucunda belirlenen hedefe ulaşmada olumlu katkılarının olduğu kabul edilmektedir (Ryan \& Deci, 2000). Günümüzde öğrenim sürecinde oldukça önemli bir beceri olan bilimsel sorgulama becerileri üzerinde öğrencilerin 
motivasyon düzeylerinin diğer faktörlere göre çok daha etkili olduğu ifade edilmektedir (Saraçoğlu \& Kahyaoğlu, 2018). Ancak öğretmenler tarafından öğrencilerin öğrenmeye yönelik motivasyonlarının dikkate alınmaması, öğretimin istenilen düzeyde gerçekleşmesini olumsuz etkilemektedir (Spitzer, 1996). Bu çalışmada ortaokul öğrencilerine yönelik olarak Türkçe dersine yönelik başarı motivasyonlarını belirlemek üzere bir ölçme aracının geliştirilmesi amaçlanmıştır. Yapılan alan yazın taramasında Erdem ve Gözüküçük (2013) tarafından yapılan ilkokul düzeyinde yer alan üç, dört ve beşinci sınıflara yönelik geliştirilen “Türkçe Dersi Motivasyon Ölçeği”nin olduğu belirlenmiştir. Ancak bu ölçek ilkokul düzeyinde olup ortaokul öğrencilerini kapsamamaktadır. Ortaokul öğrencilerinin Türkçe dersine yönelik motivasyonlarını belirlemeye yönelik bir ölçeğe rastlanmamıştır. Ancak Türkçenin kazanımlarına yönelik olarak geliştirilmiş ölçekler bulunmaktadır. Aydemir ve Öztürk (2013) tarafından ilkokul öğrencilerine yönelik olarak “Metinlere Yönelik Okuma Motivasyonu Ölçeğil" geliştirilmiştir. Ersoy ve Boyacı (2018) "Sözcük Öğrenme Motivasyonu Ölçeğ $i$ " geliştirmiştir. Türkçe ile ilgili alanlara yönelik olarak geliştirilen ölçek çalışmalarının yanı sıra uyarlama çalışmalarının da bulunduğu görülmektedir. Wigfield ve Guthrie (1997) tarafından geliştirilen “Okuma Motivasyonu Ölçeğì”nin Yıldız (2010) tarafından beşinci sınıflar düzeyinde uyarlama çalışması yapılmıştır. Yapılan alan yazın taramasında öğrencilerin Türkçe dersine yönelik motivasyonlarını ölçmek için Erdem ve Gözüküçük (2013) tarafından geliştirilen ölçek dışında doğrudan ilişkili bir ölçeğe rastlanılmaması ve bu ölçeğin de ilkokul öğrencileri ile sınırlı olması sonucunda bu ölçeğin geliştirilmesine karar verilmiştir. Geliştirilen ölçeğin ilgili alan yazına katkı sağlayacağı, bu konuda çalışma yapmak isteyen araştırmacıların kullanabileceği nitelikte bir ölçeğin ihtiyaç dâhilinde olduğu düşünülmüş ve bu doğrultuda bu çalışmanın yapılması uygun görülmüştür.

\section{Yöntem}

\section{Çalışma Grubu}

Ölçeğin geliştirilmesi amacıyla Sivas il merkezinde dört farklı ortaokulda 5, 6, 7 ve 8 . sinıflarda eğitim görmekte olan öğrenciler basit tesadüfi örnekleme yöntemi kullanılarak çalışma grubuna dâhil edilmiştir. Ölçeğin her aşamasında farklı öğrenci grubuyla 
çalışılmıştır. Ölçeğin ön uygulaması için 93, Açımlayıcı Faktör Analizi (AFA) için 369 ve Doğrulayıcı Faktör Analizi (DFA) için 568 öğrenciye uygulama yapılmıştır. Örneklem grubuna ilişkin betimsel istatistikler Tablo 1'de yer almaktadır.

Tablo 1. Örneklem grubuna ilişkin betimsel istatistikler

\begin{tabular}{|c|c|c|c|c|c|c|c|}
\hline \multirow{2}{*}{\multicolumn{2}{|c|}{ Değişkenler }} & \multicolumn{2}{|c|}{ Ön uygulama } & \multicolumn{2}{|c|}{ AFA } & \multicolumn{2}{|c|}{ DFA } \\
\hline & & $\mathrm{f}$ & $\%$ & f & $\%$ & $\mathrm{f}$ & $\%$ \\
\hline \multirow{2}{*}{ Cinsiyet } & $\mathrm{K}_{1 \mathrm{Z}}$ & 45 & 48.39 & 172 & 46.61 & 276 & 48.59 \\
\hline & Erkek & 48 & 51.61 & 197 & 53.39 & 292 & 51.41 \\
\hline \multirow{5}{*}{$\begin{array}{l}\text { Sinıf } \\
\text { Düzeyi }\end{array}$} & 5. Sinif & 24 & 25.81 & 96 & 26.02 & 106 & 18.66 \\
\hline & 6. Sinif & 20 & 21.51 & 83 & 22.49 & 135 & 23.77 \\
\hline & 7. Sinif & 24 & 25.81 & 116 & 31.44 & 146 & 25.70 \\
\hline & 8. Sinif & 25 & 26.88 & 74 & 20.05 & 181 & 31.87 \\
\hline & Toplam & 93 & 100.0 & 369 & 100.0 & 568 & 100.0 \\
\hline
\end{tabular}

Ölçeğin Geliştirilme Süreci

Türkçe Dersine Yönelik Motivasyon Ölçeği geliştirilme sürecinin ilk aşamasında ilgili alan yazın dikkatle taranmış ve aynı konuda daha önce geliştirilmiş bir ölçeğin olup olmadığı belirlenmeye çalışılmıştır. İlgili alan yazında aynı konu ve hedef kitleye yönelik başka bir ölçeğe rastlanılmamıştır. Türkçe dersinin içeriği, öğrenci kazanımları etkinlikler vb. unsurlar hakkında gerekli araştırma yapılmıştır. Daha sonra motivasyon ölçeklerinde kullanılan dil yapısı belirlenmesi amacıyla bu ölçeğin konusuyla doğrudan bağlantılı olan Erdem ve Gözüküçük (2013), Aydemir ve Öztürk (2013) ve Ersoy ve Boyacı (2018) tarafından geliştirilen ölçekler incelenmiştir. Elde edilen veriler doğrultusunda 82 maddenin yer aldığ1 madde havuzu oluşturulmuştur. Hazırlanan maddeler alan uzmanı iki öğretim üyesi, ölçek geliştirme uzmanı iki öğretim üyesi ve ortaokulda her sınıf düzeyinde ders vermiş olan dört Türkçe öğretmeni tarafından incelenmiştir. Uzmanlardan gelen öneriler doğrultusunda hedef kitlenin özelliklerine uygun olması için dil ve noktalama işaretleri yeniden düzenlenmiş, anlaşılmasının zor alacağı ifade edilen iki madde ölçekten çıkarılmıştır. Ölçek "Kesinlikle katılmıyorum" (1), "Katılmıyorum" (2), "Kısmen Katılıyorum" (3), "Katılıyorum" (4) ve "Kesinlikle katılıyorum" (5) olarak beşli likert tipinde düzenlenmiştir. Ölçek 80 madde olarak iki Türkçe öğretmeni tarafından tüm sınıf seviyesindeki birer sınıfa sesli olarak okunmuş ve öğrencilerden anlamadıkları kavramları belirtmeleri istenmiştir. Öğrencilerden olumsuz yanıt alınmaması neticesinde ilk olarak 93 ortaokul öğrencisine ön uygulama yapılmış, ölçeğin uygulanabilirlik ve anlaşılabilirliğinin belirlenmesi amaçlanmıştır. Herhangi bir sorunun görülmemesi üzerine açımlayıcı faktör analizinin yapılması amacıyla 
369 ortaokul öğrencisine uygulama yapılmıştır. Uygulama farklı eğitim bölgelerinde yer alan üç farklı ortaokulda gerçekleştirilmiştir. Açımlayıcı faktör analizi sonucunda elde edilen bulguların kontrol edilmesi amacıyla dört farklı ortaokulda öğrenim görmekte olan 568 ortaokul öğrencisine ölçeğin son hali uygulanmıştır. Uygulamalara dâhil edilen öğrencilerin ölçek sorularını hatırlamaları ve benzer cevap vermelerini önlemek amacıyla her aşamada farklı öğrenci grubuna uygulama yapılmıştır. Amos 24 programıyla veriler analiz edilmiştir. Maddelerin birbiriyle kabul edilebilir derecede uyumluluk gösterdiği belirlenmiştir.

\section{Faktör Analizi}

Elde edilen veriler istatistik paket programına yüklenmiş, kontrolleri yapılmış ve ters maddeler çevrilmiştir. Ölçek maddelerinin oluşturduğu yapının belirlenmesi amacıyla açımlayıcı faktör analizi yapılmıştır. Faktör analizindeki amaç, bir yapıda benzer özellikleri açıklayan birbiriyle bağlantılı olan maddelerin belirlenmesidir (Özdamar, 2017: 131). Ölçeğin Kaiser-Meyer-Olkin değeri .935, Bartlett's Küresellik Testi değeri ise $\chi 2=16888,796$; df=2628, p<.000 bulunmuştur. Bu değerlerle ölçeğin faktör analizine uygunluğu tespit edildikten sonra faktör analizi yapılmıştır. Ölçeğin rotasyon analizinde dik çevirme analizlerinden olan Varimax kullanılmıştır. Açımlayıcı faktör analizinden elde edilen sonuçlara göre eksi değer aldığı için 7 madde, binişik olduğu için 18 madde ve üçten az olarak faktör oluşturduğu için 5 madde ölçekten çıkarılmıştır. Ölçeğin son haliyle altı faktörden oluştuğu ve varyansın \% 64.32'ini açıkladığı görülmüştür. Ölçeğin faktörlerinin açıkladıkları varyansın iki tanesinin \%5.00'dan düşük olması sebebiyle Monte Carlo analizi yapılmış ve ölçeğin temelde dört faktörden oluştuğu tespit edilmiştir. Elde edilen bu sonuç doğrultusunda faktör sayısı dört olarak işaretlenerek analiz yapılmış ve sonuçlar kontrol edilmiştir. Bu aşamada ölçekte binişik olduğu belirlenen 5 madde daha ölçekten çıkarılmıştır. Ölçeğin 45 madde ve "Motivasyonsuzluk" (17 madde), "İçsel Motivasyon" (11 madde), "Hedef Motivasyonu" (9 madde) ve "Dışsal Motivasyon" (8 madde) olmak dört faktörden oluştuğu, ilgili varyansın \% 57. 08'ini açıkladığı belirlenmiştir. Açımlayıcı faktör analizi sonucunda elde edilen bulguların kontrol edilmesi amacıyla 4 farklı ortaokulda öğrenim görmekte olan 568 ortaokul öğrencisine ölçeğin son hali uygulanmıştır. Amos 24 programıyla veriler analiz edilmiştir. 


\section{Bulgular}

$\mathrm{Bu}$ bölümde yapılan ölçek geliştirme sürecinde açımlayıcı ve doğrulayıcı faktör analizleri ve güvenirlik analizinden elde edilen bulgulara yer almaktadır.

Açımlayııı Faktör Analizine (AFA) İlişkin Bulgular

Açımlayıcı faktör analizi sonucunda elde edilen KMO ve Bartlett's testlerine ilişkin bulgular Tablo 2'de yer almaktadir.

Tablo 2. Kaiser-Meyer-Olkin ve Bartlett'in Küresellik Testleri

\begin{tabular}{llr}
\hline Kaiser-Meyer-Olkin Örnekleme Yeterliliğinin Ölçümü. & .938 \\
\hline Bartlett'in Küresellik Testi & Ki-Kare & 11561.763 \\
& sd & 990 \\
& $\mathrm{p}$ & .000 \\
\hline
\end{tabular}

Ölçeğin yapı geçerliliğini belirlemek amacıyla 369 öğrenciye açımlayıcı faktör analizi uygulanmıştır. Açımlayıcı faktör analizinde, değişkenler arasındaki korelasyon düzeyinin belirlenmesi amaçlanmıştır. Değişkenler arasındaki korelasyonunun azalması faktör analizinden elde edilen bulgular arasındaki yani .938 olan KMO değeri, 11561.763 olan Kikare ve 990 olan serbestlik derecesi değerlerine olan güvenin de azalması anlamına gelmektedir. Anlamlılık değeri p=.000 olarak belirlendiği için değişkenler arasında bir ilişkinin bulunduğu ve korelasyon düzeyinin de yüksek olduğu kabul edilmektedir. KMO değerinin .938 olması korelasyonun oldukça yüksek, mükemmel düzeyde olduğunu göstermektedir. Örneklem büyüklüğü yeterli olarak kabul edilmektedir. Ölçeğin faktörlerine ilişkin yamaç eğim grafiği aşağıda Şekil 1'de yer almaktadır.

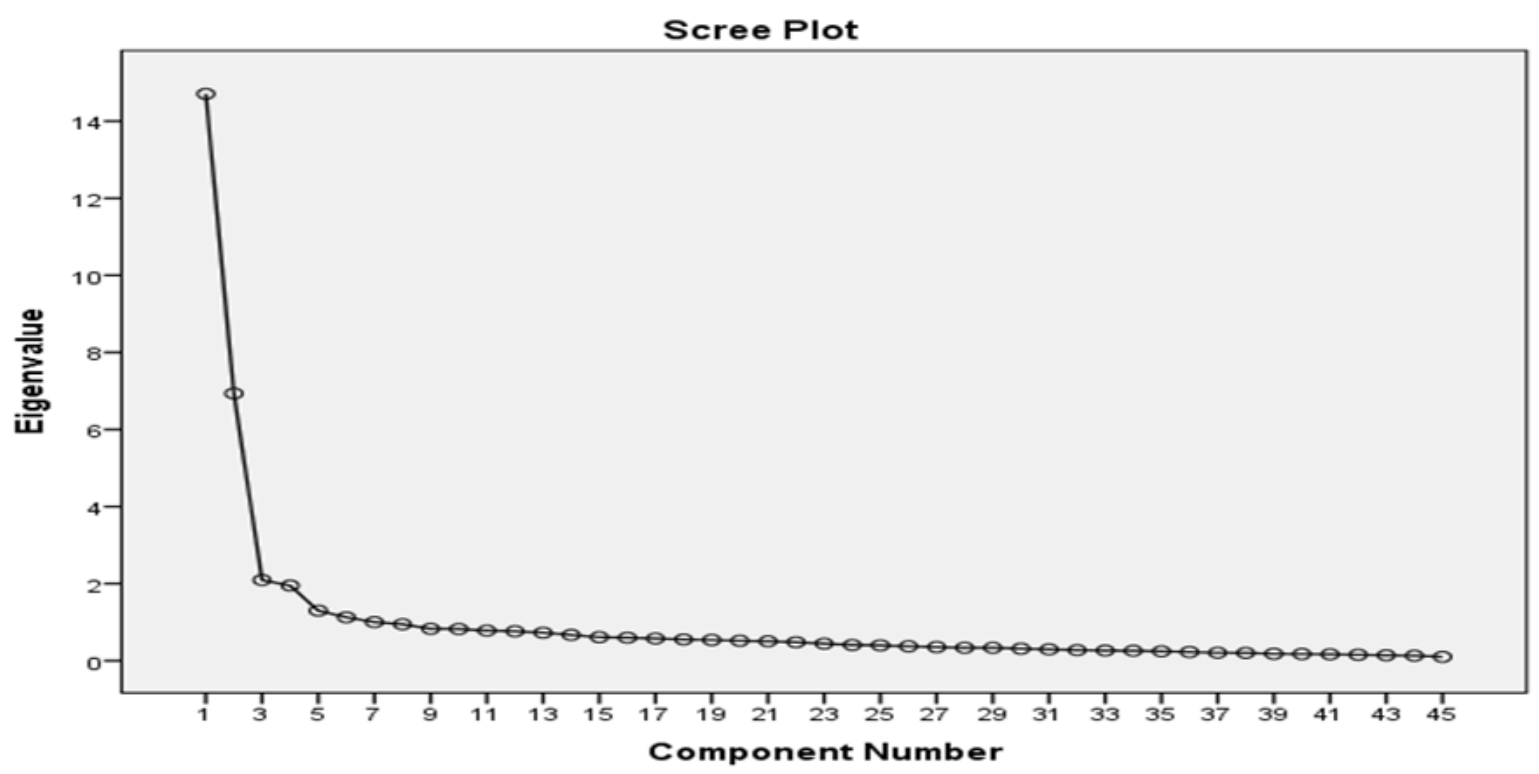

Şekil 1. Ölçeğin Scree-plot grafiği 
Şekil 1'de yer alan yamaç eğim grafiği incelendiğinde öz değeri bir ve birden fazla olarak belirlenen dört faktör olduğu için ölçeğin dört faktörden oluştuğu söylenebilir.

Temel bileşenler analizi ile kritik değerlerin öz değerlerle karşılaştırılmasına ilişkin yapılan paralel analiz sonucu Tablo 4 'te yer almaktadır.

Tablo 4. Temel Bileşenler ile Kritik Değerlerin Öz değerlerle Karşılaştırılması

\begin{tabular}{cccc}
\hline \multirow{2}{*}{ Bileşen No } & $\begin{array}{c}\text { Temel Bileșenler } \\
\text { Analizi }\end{array}$ & $\begin{array}{c}\text { Paralel Analiz Kriter } \\
\text { Değer }\end{array}$ & Karar \\
\hline 1 & 15,702 & 1.7926 & Kabul \\
2 & 7.432 & 1.7176 & Kabul \\
3 & 2.184 & 1.6515 & Kabul \\
4 & 1.960 & 1.6049 & Kabul \\
5 & 1.421 & 1.5582 & Red \\
6 & 1.333 & 1.5134 & Red \\
\hline
\end{tabular}

Yapılan Monte Carlo paralellik testi (Watkins, 2000) ölçek faktörleri ile karşılaştırılmış ve ölçeğin dört faktörünün uyumlu olduğu belirlenmiş, iki faktörü ise Monte Carlo paralel analiz kriterlerini karşılamadığı için kabul edilmemiştir. Tablo 4 'te temel bileşenler analizi (Principal Component Analysis - PCA) ile paralel analiz faktör sayısını belirlemek için rastgele veri üretilmesine dayalı bir yöntemdir. Buna göre Monte Carlo paralellik test değerlerine göre ölçeğin dört faktörlü yapıda olduğu sonucuna ulaşılmıştır. Daha sonra açımlayıcı faktör analizi dört faktör üzerinden yapılmıştır. Ölçeğin döndürülmüş faktör yüklerine ilişkin bulgular Tablo 3'te yer almaktadır.

Tablo 3. Ölçĕ̆g İlişkin Yapılan Açımlayıcı Faktör Analizi-Faktör Yükleri

\begin{tabular}{|c|c|c|c|c|}
\hline \multirow[b]{2}{*}{ Madde No } & \multicolumn{4}{|c|}{ Faktör Yükü } \\
\hline & 1. Faktör & 2. Faktör & 3. Faktör & 4. Faktör \\
\hline S69 & .861 & & & \\
\hline S70 & .848 & & & \\
\hline S71 & .846 & & & \\
\hline S79 & .842 & & & \\
\hline S65 & .830 & & & \\
\hline S72 & .829 & & & \\
\hline S66 & .821 & & & \\
\hline S61 & .812 & & & \\
\hline S75 & .793 & & & \\
\hline S64 & .791 & & & \\
\hline S77 & .791 & & & \\
\hline S76 & .777 & & & \\
\hline S78 & .776 & & & \\
\hline S63 & .774 & & & \\
\hline S62 & .769 & & & \\
\hline
\end{tabular}




\begin{tabular}{|c|c|c|c|c|}
\hline S80 & .695 & & & \\
\hline S60 & .651 & & & \\
\hline S31 & & .783 & & \\
\hline S32 & & .772 & & \\
\hline S30 & & .657 & & \\
\hline S33 & & .619 & & \\
\hline S23 & & .607 & & \\
\hline S22 & & .583 & & \\
\hline S25 & & .565 & & \\
\hline S21 & & .556 & & \\
\hline S24 & & .555 & & \\
\hline S11 & & .526 & & \\
\hline S28 & & .439 & & \\
\hline S19 & & & .775 & \\
\hline S18 & & & .746 & \\
\hline S16 & & & .724 & \\
\hline S17 & & & .709 & \\
\hline S20 & & & .698 & \\
\hline S15 & & & .626 & \\
\hline S50 & & & .614 & \\
\hline S51 & & & .579 & \\
\hline S6 & & & .441 & \\
\hline S45 & & & & .731 \\
\hline S47 & & & & .696 \\
\hline S41 & & & & .661 \\
\hline S42 & & & & .649 \\
\hline S58 & & & & .630 \\
\hline S40 & & & & .626 \\
\hline S48 & & & & .560 \\
\hline S53 & & & & .497 \\
\hline Açıklanan Varyans & 32.686 & 15.410 & 4.652 & 4.332 \\
\hline
\end{tabular}

Tablo 3'te görüldügü üzere ölçek dört faktörden oluşmakta ve toplam varyansın \% 57.08'ini açılamaktadır. Ölçeğin faktörlerinin toplam varyansı açıklama yüzdelerine bakıldığında; ilk faktörünün \%32.69, ikinci faktörünün \% 15.41, üçüncü faktörünün \% 4.65 ve dördüncü faktörünün \% 4.33’lük bir kısmını açıkladı̆̆ı görülmektedir. Ölçeğin toplam açıkladığı varyansın \% 50 ve üzerinde olması beklenmektedir. Bu doğrultuda ölçeğin açıkladığı varyansın istenilen yeterlikte olduğu görülmektedir.

Açımlayıcı faktör analizinde maddelerin farklı faktörlerdeki faktör yükleri arasında .10’luk farkın bulunup bulunmadığına yani binişikliğine dikkat edilmiştir. Madde yük değerlerinin .040'dan büyük olmasına özen gösterilmiştir. Ayrıca bu işlemler birkaç kez tekrar edildikten ve adım adım ilerledikten sonra ölçeğe son şekli verilmiştir.

Açımlayıcı faktör analizi sonucunda ölçeğin 4 faktör ve 45 maddeden oluştuğu, ölçekte yer alan maddelerin faktör yükleri ve hangi faktörde yer aldıkları belirlenmiştir. 
Faktörlere sirasıyla "Motivasyonsuzluk" (17 madde), "İçsel Motivasyon" (11 madde), "Hedef Motivasyonu" (9 madde) ve "Dışsal Motivasyon" (8 madde) isimleri verilmiştir. Ölçeğin faktörleri ve yer aldıkları maddelere ilişkin bulgular Tablo 5'te yer almaktadır.

Tablo 5. Türkçe Dersine Yönelik Motivasyon Ölçeğine Yönelik Değerler

\begin{tabular}{|c|c|c|c|}
\hline Faktör & Faktör adı & İlgili maddeler & $\begin{array}{c}\text { Alınabilecek min. ve } \\
\text { max. Puan }\end{array}$ \\
\hline Birinci faktör & Motivasyonsuzluk & $\begin{array}{l}60,61,62,63,64,65,66,69 \\
70,71,72,75,76,77,78,79,80\end{array}$ & $17-85$ \\
\hline İkinci faktör & İçsel motivasyon & $\begin{array}{l}11,21,22,23,24,25,28,30, \\
31,32,33\end{array}$ & $11-55$ \\
\hline Üçüncü faktör & Hedef motivasyonu & $6,15,16,17,18,19,20,50,51$ & $9-45$ \\
\hline $\begin{array}{l}\text { Dördüncü } \\
\text { faktör }\end{array}$ & Dişsal motivasyon & $40,41,42,45,47,48,53,58$ & $8-40$ \\
\hline
\end{tabular}

Tablo 5 incelendiğinde ölçeğin maddelerinin yer aldı̆̆1 faktörler görülmektedir. Ölçekteki maddeler "Kesinlikle katılmıyorum" (1), "Katılmıyorum" (2), "Kısmen katılıyorum" (3), "Katılıyorum" (4) ve "Kesinlikle katılıyorum" (5) şeklinde 5'li likert olarak hazırlanmıştır. Ölçekteki 29, 30, 31, 32, 33, 34, 35, 36, 37, 38, 39, 40, 41, 42, 43, 44 ve 45 . maddeler ters puanlanmaktadir.

Doğrulayıcı Faktör Analizine (DFA) İlişkin Bulgular

45 madde ve üç faktörden oluşan ölçek 568 öğrenciye uygulanmış ve doğrulayıcı Faktör Analizi (DFA) ile teste tabi tutulmuştur. DFA'ya ilişkin path diyagramı aşağıda verilmiştir. 


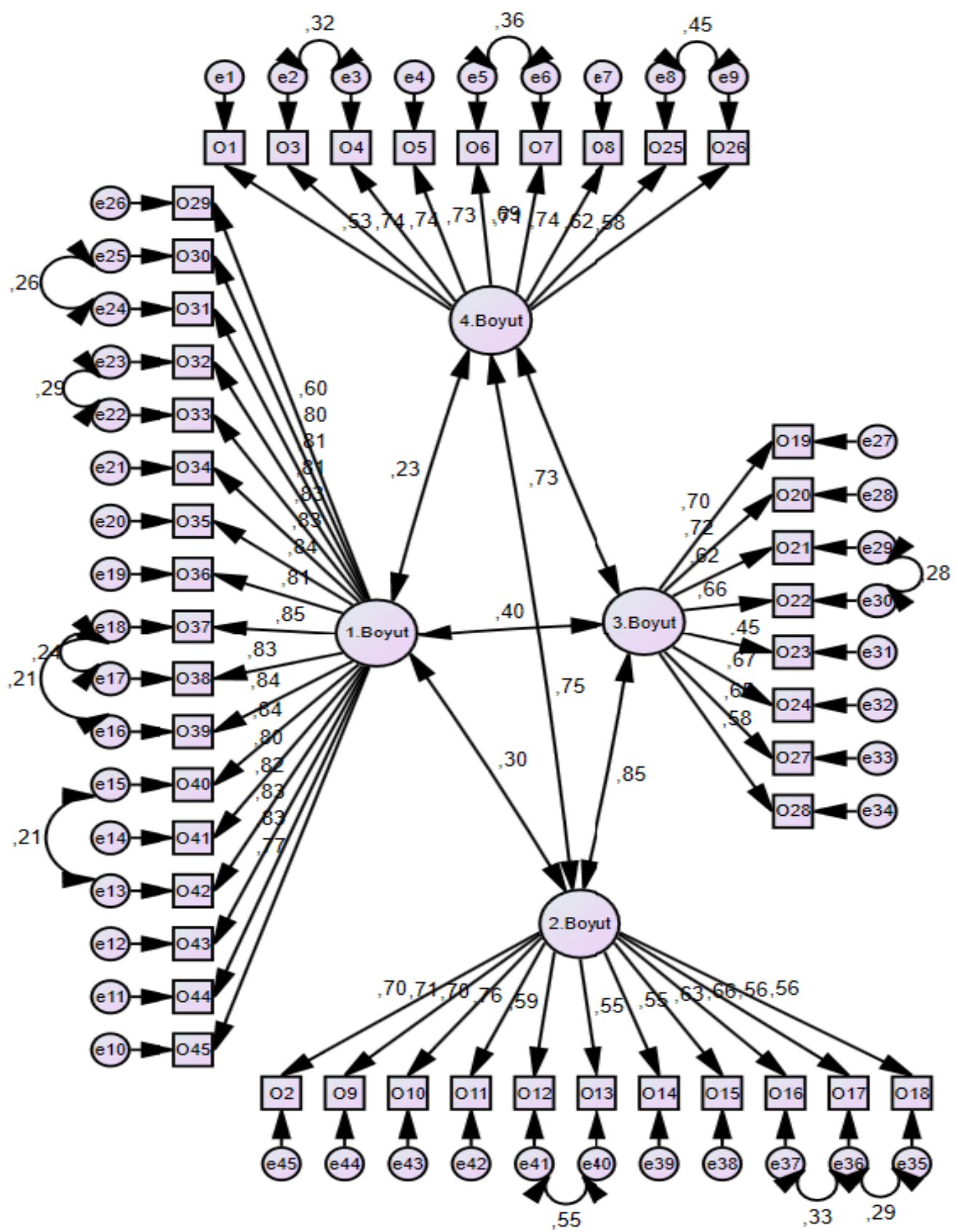

Şekil 2. DFA sonuçları

Doğrulayıcı faktör analizi sonucunda 1. faktörün 17 maddeden oluştuğu, 2. faktörün 11 maddeden oluştuğu, 3. faktörün 9 maddeden oluştuğu ve 4 . faktörün ise 8 maddeden oluştuğu görülmektedir.

Model uyumu (model fit) için, model ile veri arasındaki uyumu test ederken, uyum iyiliği testlerinden birkaçı kullanılabildiği gibi, hepsinin de kullanılması tercih edebilir (McMillan \& Schumacher, 2006: 120). Bu uyum iyiliği istatistiklerinden hangisinin kullanılacağına dair alan yazında tam bir uzlaşı bulunmamaktadır (İlhan ve Çetin 2014: 3031). Model uyumu (model fit) için genel olarak bakılan değerler; $\chi^{2} / \mathrm{df}$, SRMR, AGFI, NFI, 
TLI, CFI ve RMSEA değerleridir. Şekil 2 incelendiğinde, 45 madde ve dört faktörden oluşan ölçeğin Ki-kare uyum indekslerinin anlamlı olduğu görülmüştür $\left(X^{2} / s d=2,260\right)$. Uyum indeksi değerleri ise $\mathrm{RMSEA}=.047, \mathrm{SRMR}=.046, \mathrm{CFI}=.93, \mathrm{AGFI}=.87, \mathrm{NFI}=.90$ olarak bulunmuştur. Uyum indeksleri incelendiğinde, elde edilen ölçeğin uyum indekslerinin iyi uyum ve kabul edilebilir uyum indeksi değerleri arasında yer aldığı tespit edilmiştir. DFA'ya ait uyum indeksleri ve literatürde belirtilen referans aralıkları (Hooper, Coughlan \& Mullen, 2008; Schermelleh-Engel, Moosbrugger \& Müller, 2003) ile oluşturulan model ile ilgili uyum değerleri aşağıda Tablo 6' da verilmiştir.

Tablo 6. DFA'ya Ait Uyum İndeksleri

\begin{tabular}{cclcc}
\hline \multirow{2}{*}{ İndeksler } & \multicolumn{2}{c}{ Referans Değeri } & Ölçüm & Sonuç \\
\cline { 2 - 3 } & $\begin{array}{c}\text { Kabul Edilebilir } \\
\text { Uyum }\end{array}$ & İyi Uyum & & \\
\hline CMIN/DF & $3<\chi 2 /$ sd $\leq 5$ & $0<\chi 2 /$ sd $\leq 3$ & 2.260 & İyi Uyum \\
TLI & $.90<$ TLI $\leq .94$ & $.95<$ TLI $\leq 1$ & .926 & Kabul Edilebilir Uyum \\
RMSEA & $.05 \leq$ RMSEA $\leq .08$ & $0 \leq$ RMSEA $\leq .05$ & .047 & İyi Uyum \\
SRMR & $0.05 \leq$ SRMR $\leq .10$ & $0 \leq$ SRMR $\leq .05$ & .046 & İyi Uyum \\
CFI & $.90<$ CFI $\leq .94$ & $.95<$ CFI $\leq 1$ & .931 & Kabul Edilebilir Uyum \\
AGFI & $.85<$ AGFI $\leq .89$ & $.90<$ AGFI $\leq 1$ & .87 & Kabul Edilebilir Uyum \\
NFI & $.90<\mathrm{NFI} \leq .94$ & $.95<\mathrm{NFI} \leq 1$ & .90 & Kabul Edilebilir Uyum \\
Sd & & & 342 & \\
\hline
\end{tabular}

Tablo 6'da doğrulayıcı faktör analizi sonucunda elde edilen uyum değerlerine göre model, verilere iyi uyum ve kabul edilebilir uyum göstermektedir. Dolayısıyla, açımlayıcı faktör analizi ile bulunan Türkçe dersine yönelik motivasyon ölçeğinin geçerliliği, doğrulayıcı faktör analizi ile de teyit edilmiş olmaktadır. Geliştirilen ölçek Türkçe dersine yönelik motivasyonu ölçmek için kullanılabilir. Regresyon değerleri, gözlenen değişkenlerin, gizli değişkenleri tahmin etme gücünü, yani faktör yüklenimlerini göstermektedir. Ölçeğin, standardize edilmiş regresyon katsayıları kabul edilebilir sınırlar içerisinde çıkmıştır.

Ölçeğin son uygulamasına ait verilerin güvenirliğinin belirlenebilmesi için öncelikle hem ölçeğin tamamının hem de oluşan dört faktörün Cronbach Alpha değerleri hesaplanmış ve Tablo 7'de sunulmuştur. 
Tablo 7. Ölçeğin Son Uygulamasına ve Faktörlerine Ait Cronbach Alpha Değerleri

\begin{tabular}{llc}
\hline \multicolumn{2}{c}{ Faktörler } & Cronbach Alpha Değeri \\
\hline Motivasyonsuzluk & 1. Faktör -17 madde & .97 \\
İçsel motivasyon & 2. Faktör -11 madde & .89 \\
Hedef motivasyonu & 3. Faktör -9 madde & .89 \\
Dişsal motivasyon & 4. Faktör -8 madde & .86 \\
Toplam & 45 madde & .95 \\
\hline
\end{tabular}

Tablo 7'de görüldüğü üzere ölçeğin son uygulamasının faktörlerine ilişkin Cronbach Alpha değerleri .86 ve .97 aralığında bulunmaktadır. Ölçeğin Cronbach's Alpha güvenirlik kat sayısı motivasyonsuzluk faktöründe .97, içsel motivasyon faktöründe .89, hedef motivasyonu faktöründe .89 , dışsal motivasyon faktöründe .86 olarak bulunmuştur. Ölçeğin tamamına ilişkin Cronbach Alpha değerinin ise .95 olarak belirlenmesi ölçek son uygulamasının yüksek derecede güvenilir olduğunu göstermektedir. Ölçeğin son uygulamasında ölçek güvenilirliğinin tekrar değerlendirilmesinde iki yarı test tekniğinden de yararlanılmıştır. İki yarı test değerleri Tablo 8' de gösterilmektedir.

Tablo 8. Ölçeğin Son Uygulamasına Ait İki Yarı Test Değerleri

\begin{tabular}{cc}
\hline Ölçeğin Bölümleri & Cronbach Alpha \\
\hline 1. Bölüm & .92 \\
2. Bölüm & .95 \\
\hline
\end{tabular}

Tablo 8'deki bulgulara göre ölçeğin iki yarı test sonucunun Cronbach Alpha değeri 1. bölüm için .92, 2. bölüm için ise .95 olarak belirlenmiştir. Ölçek son uygulama sonucunda uygulanan iki yarı test sonuçlarından elde edilen değerlere göre de ölçeğin yüksek derecede güvenilir olduğu sonucuna ulaşılmıştır.

Ölçeğin faktörlerinin birbirleri ve toplamıyla korelasyonunun belirlenmesi amacıyla yapılan Pearson Korelasyon analizi sonuçları Tablo 9'da yer almaktadır.

Tablo 9. Ölçek Faktörleri ve Toplam Puana İlişkin Korelasyon Analizi Sonuçları

\begin{tabular}{lccccc} 
& $\begin{array}{c}\text { Motivasyon } \\
\text { Toplam }\end{array}$ & Motivasyonsuzluk & $\begin{array}{c}\text { İçsel } \\
\text { Mot. }\end{array}$ & $\begin{array}{c}\text { Etkinlik } \\
\text { Mot. }\end{array}$ & $\begin{array}{c}\text { Dişsal } \\
\text { Mot. }\end{array}$ \\
\hline Motivasyon Top & 1.00 & $.78^{* *}$ & $.73^{* *}$ & $.74^{* *}$ & $.75^{* *}$ \\
\hline Motivasyonsuzluk & & 1.00 & .26 & .27 & $.38^{* *}$ \\
\hline İçsel Mot. & & & 1.00 & $.57^{* *}$ & $.58^{* *}$ \\
\hline Etkinlik Mot. & & & & 1.00 & $.58^{* *}$ \\
\hline Dişsal Mot. & & & & 1.00 \\
\hline
\end{tabular}


Tablo 9'daki bulgular incelendiğinde; ölçeğin toplam puanı ile faktörleri arasında pozitif yönde yüksek düzeyde bir ilişkinin olduğu görülmektedir. Ölçek toplam puanı ile motivasyonsuzluk faktörü arasında pozitif yönde yüksek düzeyde (r=.78), içsel motivasyon faktörü arasında pozitif yönde yüksek düzeyde (r=.73), hedef motivasyonu faktörü arasında pozitif yönde yüksek düzeyde $(r=.74)$, dişsal motivasyon faktörü arasında pozitif yönde yüksek düzeyde (r=.75) bir ilişki tespit edilmiştir. Ölçeğin faktörleri arasındaki korelasyon düzeylerinin ise $(\mathrm{r}=.26)$ ile $(\mathrm{r}=.58)$ arasında değiştiği görülmektedir. Ölçeğin motivasyonsuzluk faktörünün içsel ve etkinlik faktörleri ile düşük düzeyde korelasyon gösterdiği, dışsal motivasyon ile orta düzeyde korelasyon gösterdiği; diğer faktörlerin ise birbirleri arasında orta düzeyde korelasyon gösterdiği belirlenmiştir.

\section{Tartışma ve Sonuç}

Bu çalışmada Türkçe Dersine Yönelik Motivasyon Ölçeği geliştirilmiş olup Sivas il merkezinde yürütülmüştür. Ölçeği geliştirebilmek için, yapisal eşitlik modellemesi kullanılmıştır. Ölçek maddelerine öncelikle açımlayıcı faktör analizi uygulanarak ölçeğin faktörleri belirlenmiştir. Sonrasında belirlenen faktörlerin temel bileşenler analizi ile kritik öz değerlerle karşılaştırılması amacıyla paralel analiz teknikleri içinde yer alan Monte Carlo analizi yapılmıştır. Yapılan Monte Carlo paralellik testi sonucuyla ölçek faktörleri ile karşılaştırılmış ve ölçeğin dört faktörlü olduğu belirlenmiştir. Açımlayıcı faktör analizi sonucunda belirlenen iki faktör ise gerekli şartları oluşturmadığı için kabul edilmemiştir. Kabul edilen faktörlere doğrulayıcı faktör analizi uygulanmıştır. Elde edilen model uyum (model fit) değerlerine göre model, $X^{2} / d f=2.260, \mathrm{TLI}=926, \mathrm{RMSEA}=.047$, SRMR $=.046$, $\mathrm{CFI}=.931, \mathrm{AGFI}=.87, \mathrm{NFI}=.90$ verilere kabul edilebilir uyum gösterdiği belirlenmiştir .

Ölçek toplam varyansın \%57.08'ini açılamaktadır. Ölçeğin toplam açıkladığı varyansın \%50 ve üzerinde olması beklenmektedir. Bu doğrultuda ölçeğin açıkladığı varyansın istenilen yeterlikte olduğu görülmektedir.

Açımlayıcı faktör analizi elde edilen rotasyonlu (dönüşümlü) faktör yüklerine göre ölçek, 45 soruyu içeren 4 faktörden oluşmuştur. Faktörlerdeki maddelerin taşıdıkları anlam dikkate alınarak, faktörlere isim verilmiştir. Ölçeğin; "Motivasyonsuzluk", "İçsel Motivasyon", "Hedef Motivasyonu" ve "Dışsal Motivasyon" şeklinde dört faktörden ve ilgili varyansın \% 57. 08'ini açıkladığı belirlenmiştir. Faktörlerdeki maddelerin taşıdıkları anlam dikkate alınarak, 
faktörlere isim verilmiştir. Ölçeğin yapı geçerliliği için 369 öğrenciye açımlayıcı faktör analizi yapilmiştır.

Bu çalışmada; ortaokul düzeyindeki öğrencilerin Türkçe dersine yönelik motivasyon düzeylerini ölçebilecek özellikte bir ölçek geliştirmektir. Bu doğrultuda yürütülen bu çalışma sonucunda elde edilen bulgular ölçeğin belirlenen amaca hizmet edebilecek nitelikte olduğu görülmektedir. Ölçeğin toplam ve faktörlerine ilişkin güvenirlik düzeyinin yüksek olduğu belirlenmiştir. Türkçe dersine yönelik motivasyon ölçeğinin geçerliliği, doğrulayıcı faktör analizi ile de teyit edilmiş ve ölçeğin ortaokul öğrencilerinin Türkçe dersine yönelik motivasyon düzeylerini ölçmek için kullanılabileceğine karar verilmiştir. Ortaokul düzeyindeki öğrencilerin Türkçe dersine yönelik motivasyonlarını belirlemek için geliştirilen bu ölçekle farklı değişkenler kullanılarak araştırma yapılabilir.

\section{Kaynaklar}

Alexander, P.A., \& Murphy, P.K. (1998). Profiling the differences in students' knowledge, interest, and strategic planning. Journal of Educational Psychology, 90, 435-447.

Ames, C. (1990). Motivation: What teachers need to know. Teachers College Record, 91(3), 409421.

Ames, C. (1992). Classrooms, goals, structures and student motivation. Journal of Educational Psycholog, 84(3), 261-271.

Aslan, Z., \& Cengiz, E. (2015). Akademisyenlerin iş stresi ile iş motivasyonu ilişkisi. Gümüşhane Üniversitesi Sosyal Bilimler Dergisi, 12, 25-43.

Ataman, O. (2017). Üniversite hazırlık sınıfı öğrencilerinin İngilizce öğrenmeye yönelik motivasyon düzeyleri ve tutumları ile hazırlık sınıf başarı puanları arasındaki ilişki. Yayınlanmamış Yüksek Lisans Tezi. Sakarya Üniversitesi Eğitim Bilimleri Enstitüsü, Sakarya.

Aydemir, Z., \& Öztürk, E. (2013). Metinlere yönelik okuma motivasyonu ölçeği: Geçerlik ve güvenirlik çalışması. İlköğretim Online, 12(1), 66-76.

Aydın, B. (2007). Fen bilgisi dersinde içsel ve dışsal motivasyonun önemi. Yayınlanmamış Yüksek Lisans Tezi. Yeditepe Üniversitesi. İstanbul.

Başaran, İ.E. (1996). Ĕ̆itime giriş. İstanbul: Umut Yayın Dağıtım.

Bandura, A. (1993). Perceived self-efficacy in cognitive development and functioning. Educational Psychologist, 28(2), 117-148.

Deci, E.L., \& Ryan, R.M. (1985). Intrinsic motivation and self-determination in human behavior. New York: Plenum Press.

Deci, E.L., \& Ryan, R.M. (2000). The "what" and "why" of goal pursuits: human needs and the self-determination of behavior. Psychological Inquiry, 11(4), 227-268. 
Demirel, Y. (2007). İlköğretim okulu yöneticilerinin branş öğretmenlerini motive etmede kullandıkları yöntemlere ilişkin yönetici ve öğretmen görüşleri. Yayınlanmamış Yüksek Lisans Tezi. Beykent Üniversitesi, Sosyal Bilimler Enstitüsü, İstanbul.

Dörnyei, Z. (1998). Motivation in second and foreign language learning. Language Teaching, 31(3), 117-135.

Dörnyei, Z., \& Otto, I. (1998). Motivation in action: A process model of 12 motivation. Working Papers in Applied Linguistics, 4, 43-69.

Erdem, A.R., \& Gözüküçük, M. (2013). İlköğretim 3. 4. ve 5. sınıf öğrencilerinin Türkçe dersine yönelik motivasyonu ve tutumları arasındaki ilişki. Pegem Eğitim ve Öğretim Dergisi, 3(2), 13-24.

Ersoy, B.G., \& Boyacı, Ş.D.B. (2018). Sözcük öğrenme motivasyonu ölçeği (SÖMÖ): geçerlik ve güvenirlik çalışması. İlköğretim Online, 17(1), 255-267.

Hooper, D., Coughlan, J., \& Mullen, M. R. (2008). Structural equation modelling: guidelines for determining model fit. Electronic Journal of Business Research Methods, 6(1), 53-60.

Ilgar, L. (2000). Eğitim yönetimi okul yönetimi sınıf yönetimi. İstanbul: Beta Yayınları.

İlhan, M., \& Çetin, B. (2014). LISREL ve AMOS programları kullanılarak gerçekleştirilen yapısal eşitlik modeli (YEM) analizlerine ilişkin sonuçların karşılaştırılması. Eğitimde ve Psikolojide Ölçme ve Değerlendirme Dergisi, 5(2), 26-42.

Koçel, T. (2014). İşletme yöneticiliğii. (15. basım). İstanbul: Beta Yayıncılık.

Locke, E.A. (1996). Motivation through conscious goal setting. Applied and Preventive Psychology, 5, 117-24.

Lumsden, L.S. (1994). Student motivation to learn. ERIC, 92. ED370200

McMillan, J.H., \& Schumacher, S. (2006). Research in education: Evidence- based inquiry. (8. edt.). Boston, MA: Allyn and Bacon.

Odabaş, S. (2011). Ĕ̆gitim bilimlerinde yeni yaklaşımlar. Ankara: Yediiklim Yayıncılık.

Özdamar, K. (2017). Ölçek ve test geliştirme yapısal eşitlik modellemesi. Eskişehir: Nisan Kitabevi.

Pintrich, P., \& Schunk, D. (1996). Motivation in education. New Jersey, USA: Prentice Hall.

Ryan, R.M., \& Deci, E.L. (2000). Intrinsic and extrinsic motivations: Classic definitions and new directions. Contemporary Educational Psychology, 25, 54-67.

Saraçoğlu, M., \& Kahyaoğlu, M. (2018). Ortaokul öğrencilerinin bilimsel sorgulama becerileri algilarının, merak, motivasyon ve tutum açısından incelenmesi. Journal of Computer and Education Research, 6(12), 358-376.

Schermelleh- Engel, K., Moosbrugger, H., \& Müller, H. (2003). Evaluating the fit of structural equation models: Tests of significance and descriptive goodness-of-fit measures. Methods of Psychological Research Online, 8(2), 23-74.

Schunk, D.H. (2009). Öğrenme teorileri: Ĕ̆gitimsel bir bakışla. (M. Şahin, çev. ed.). Ankara: Nobel Yayınları.

Spitzer, D. (1996). Motivation: The neglected factor in instructional design. Educational Technology, 36(3), 45-49. 
Viau, R. (2015). Okulda motivasyon okulda güdüleme ve güdülenmeyi öğrenme (Budak, Y. çev.). Ankara: Anı Yayıncilik.

Watkins, M.W. (2000). Monte Carlo PCA for parallel analysis - computer software. State Collage, PA: Ed \& Psych Associates.

Weiner, B. (1979). A theory of motivation for some classroom experiences. Journal of Educational Psychology. 71, 3-25.

Wigfield, A., \& Guthrie, J. T. (1997). Çocukların okumaya yönelik motivasyonun miktar ve genişliğe veya okumalarına ilişkin ilişkileri. Eğitim Psikolojisi Dergisi, 89(3), 420.

Wolters, C. A. (1999). The relation between high school students' motivational regulation and their use of learning strategies, effort, and classroom performance. Learning and Individual Differences,11(3), 281-300.

Yapar, T. (2005), Motivasyonun iş verimliliği üzerine etkisi. Yayınlanmamış Yüksek Lisans Tezi. İstanbul Üniversitesi Sosyal Bilimler Enstitüsü, İstanbul.

Y1ldız, M. (2010). İlköğretim 5. sinıf öğrencilerinin okuduğunu anlama, okuma motivasyonu ve okuma alışkanlıkları arasındaki ilişki. Yayınlanmamış Doktora Tezi. Gazi Üniversitesi Eğitim Bilimleri Enstitüsü, Ankara. 
EK 1. Türkçe Dersine Yönelik Motivasyon Ölçeği

İFADELER

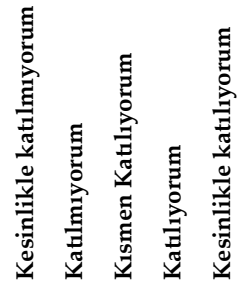

1. Dinleme becerimi geliştirmek için dinleme etkinliklerine katıllyorum.

2. Türkçe dersini sevdiğim için konuşma etkinliklerini zevkle katılıyorum.

3. Okuduğum metinleri doğru anlamak için okuma kurallarını öğrenmek istiyorum.

4. Okuduğum metinleri doğru anlamak için okuma yöntemlerini öğrenmek istiyorum.

5. Dilbilgisi kurallarına uygun yazı yazabilmek için yazım kurallarını öğrenmek istiyorum.

6. Etkili konuşma yapabilmek için konuşma kurallarını öğrenmek istiyorum.

7. Etkili konuşma yapabilmek için konuşma yöntemlerini öğrenmek istiyorum.

8. Öğrenmemi olumlu etkilediği için dinleme kurallarını öğrenmek istiyorum.

9. Türkçe dersinde kendimi mutlu hissettiğim için derse etkin katılıyorum.

10. Türkçe dersindeki konuları sevdiğim için öğretmenin söylediklerini takip ediyorum.

11. Türkçe dersi etkinliklerini sevdiğim için derse etkin katılıyorum.

12. Türkçe dersini sevdiğim için ders saatinin artırılmasını istiyorum.

13. Türkçe dersin önemli olduğu için ders saatinin artırılmasını istiyorum.

14. Türkçe dersini sevdiğim için sinffta en önde oturmak istiyorum.

15. Türkçe dersinde başarılı olmak için ders başlamadan önce derse yönelik hazırlık yapiyorum.

16. Türkçe dersinde başarılı olmak için planlı çalışıyorum.

17. Türkçe dersinde öğrendiklerimin kalıcı olması için dersten sonra konu tekrarı yapıyorum.

18. Türkçe dersinde başarılı olmak için derste öğrendiğim konuyla ilgili soru çözüyorum.

19. Türkçe dersindeki konular önemli olduğu için öğrenmek istiyorum.

20. Türkçe dersinde yüksek not almak için öğretmeni dikkatli dinliyorum.

21. Ailemi mutlu etmek için Türkçe dersinde başarılı olmak istiyorum.

22. Öğretmenin takdirini kazanmak için Türkçe dersinden yüksek not almak istiyorum.

23. Arkadaşlarıma örnek gösterilmek için Türkçe dersinden yüksek not almak istiyorum.

24. Öğrendiğim bilgiler diğer derslerdeki başarımı etkilediği için Türkçe dersini takip ediyorum.

25. Türkçe sınavlarında yüksek not almak için yazma kurallarını öğrenmek istiyorum.

26. Türkçe sınavlarında yüksek not almak için okuma kurallarını öğrenmek istiyorum.

27. Öğretmenimi çok sevdiğim için Türkçe dersinde başarılı olmak istiyorum.

28. Türkçe dersinden aldığım sınav notu yılsonu başarı ortalamamı etkilediği için dersi

28. dikkatli takip ediyorum.

29. Yanlış cevap verdiğimde arkadaşlarım benimle alay edeceği için Türkçe dersini takip etmiyorum.

30. Önemsiz olduğu için Türkçe dersini takip etmiyorum.

31. Boşa zaman harcadığımı düşündüğüm için Türkçe dersini takip etmiyorum.

32. Sevmediğim için Türkçe dersini takip etmiyorum.

33. Sıkıcı olduğu için Türkçe dersini takip etmiyorum.

34. Yüksek not almam gereksiz olduğu için Türkçe dersini takip etmiyorum.

35. Başka dersleri daha çok sevdiğim için Türkçe dersini takip etmiyorum.

36. Türkçe dersindeki okuma etkinliklerine gereksiz bulduğum için katılmıyorum.

37. Türkçe dersindeki yazma etkinliklerini gereksiz bulduğum için yapmiyorum.

38. Türkçe dersindeki konuşma etkinliklerine gereksiz bulduğum için katılmıyorum.

39. Türkçe dersindeki dinleme etkinliklerine gereksiz bulduğum için katılmıyorum.

40. Türkçe dersini sevmediğim için okula gelmek istemiyorum.

41. Türkçe öğretmenimi sevmediğim için derse etkin katılmıyorum.

42. Gelecekte bana yararlı olmayacağı için Türkçe dersini takip etmiyorum.

43. Türkçe dersini sevmediğim için ödevlerini yapmıyorum.

44. Öğretilen bilgiler gereksiz olduğu için Türkçe dersini takip etmiyorum.

45. Türkçe dersinde sürekli uykum geldiği için dersi takip etmiyorum. 